Revue Française de Civilisation Britannique

\title{
BBC Arabic (1938-1995): Soft Power or Reithian Practice Abroad?
}

Le Service arabe de la BBC, 1938-1995: Soft Power ou pratique reithienne à l'étranger?

\section{Houcine Msaddek}

\section{OpenEdition}

\section{Journals}

Electronic version

URL: https://journals.openedition.org/rfcb/7056

DOI: $10.4000 /$ rfcb.7056

ISSN: 2429-4373

\section{Publisher}

CRECIB - Centre de recherche et d'études en civilisation britannique

\section{Electronic reference}

Houcine Msaddek, "BBC Arabic (1938-1995): Soft Power or Reithian Practice Abroad?", Revue Française de Civilisation Britannique [Online], XXVI-1 | 2021, Online since 05 December 2020, connection on 05 January 2022. URL: http://journals.openedition.org/rfcb/7056 ; DOI: https://doi.org/10.4000/ rfcb.7056

This text was automatically generated on 5 January 2022.

\section{cc) (†)}

Revue française de civilisation britannique est mis à disposition selon les termes de la licence Creative Commons Attribution - Pas d'Utilisation Commerciale - Pas de Modification 4.0 International. 


\title{
BBC Arabic (1938-1995): Soft Power or Reithian Practice Abroad?
}

\author{
Le Service arabe de la BBC, 1938-1995: Soft Power ou pratique reithienne à \\ l'étranger?
}

Houcine Msaddek

I dedicate this work in memory of my father who was a devoted listener of BBC Arabic in the nineteen-sixties and throughout the seventies.

\section{Introduction}

BBC Arabic is both the largest and oldest of the British Broadcasting Corporation's nonEnglish language services. Launched in January 1938 in an almost direct response to Mussolini's increasingly provocative anti-British Arabic language broadcasts aired from Bari, the Arabic Service of the BBC has constantly cultivated the loyalty of millions of listeners in the Middle East and North Africa ever since. Throughout the post-war period and up to the mid-1990s radio remained the primary medium of information and entertainment in many parts of the Arab world and the BBC's constant challenge was to live up to its reputation in the region as a broadcasting organisation that was thought to be only telling the truth. Yet, in that diplomatically and geopolitically sensitive region successive historic events, such as the Suez crisis in 1956 or the 1991 Gulf War, were bound to put to the test the Corporation's principled commitment to providing accurate, unbiased, independent news information and analysis. In addition to impartial news reporting, the $\mathrm{BBC}$ also built a reputation for excellent educational and recreational programmes, both at home and abroad, which from the start posed a further challenge to the emerging foreign language service. To live up to those founding objectives and reputation, the Corporation's early and recurrent recruitment among the Arab diaspora of intellectuals, writers and high-profile journalists proved to be the missing link between the broadcaster and its target audience. Names of many of 
those recruits became household names in the region. The key role they played in the Corporation bears a remarkable creative and diplomatic significance. While the task assigned to them by statute was to reflect the UK, its culture and values and to broadcast a balanced and objective service of world news for the benefit of their listeners, only an in-depth assessment of the output they produced and broadcast over the decades can attest to the extent to which they helped to establish and renew the Corporation's rank and status as the world's most credible and attractive international broadcaster.

2 Although BBC Arabic has been the subject of several scholarly studies, ${ }^{1}$ the Service's heavy reliance on native Arab recruits has rarely been addressed in a comprehensive way. Who were these recruits? In what way did British diplomacy make use of the most high-profile figures among them? How far did this interfere with John Reith's ${ }^{2}$ concept of a dedicated public service guarded from political interference? In what way did they contribute to the BBC's long-standing mission to "inform, educate and entertain" and succeed in creating a cultural bridge between them and their large audience hence "sowing far and wide the good seeds" of the Corporation's ethics and standards, to recall the emblematic sculpture in Broadcasting House reception hall? ${ }^{3}$

What subsequently became known as the BBC World Service (BBCWS), ${ }^{4}$ has long been a key employer of hundreds of diasporic broadcasters and multilingual migrants for the Corporation's forty or so foreign language services. Often linked in people's memories to Bush House, its historic central London headquarters, ${ }^{5} \mathrm{BBCWS}$ is probably one of the world's largest sites of diasporic cultural creativity. From 2007 to 2012 the UK Open University, in partnership with the BBC, carried out a series of empirically grounded case studies analysing the exercise of British "soft power" through the BBC's foreign language services, and the diplomatic role played by their diasporic broadcasters in mediating relations between the UK government, the $\mathrm{BBC}$ and overseas audiences. The published findings of the Open University seminars ${ }^{6}$ constitute a valuable contribution to academic theorisations of the dynamics of diasporas dealt with here. Limiting itself to those who worked for the Arabic Service, this paper sets out to bring to light generations of invisible and forgotten Arab contributors to the BBC's success story. While the role and impact of individual Arabic-speaking broadcasters constitute a leitmotiv throughout the article, the specific case I am investigating concerns the legacy of BBC Arabic Service as such within BBCWS and the latter's position in the wider $\mathrm{BBC}$.

4 The $\mathrm{BBC}$ Archives constitute an impressive body of primary sources though unfortunately they were not fully accessible during this research work. ${ }^{7}$ I also draw on some other sources of information, notably the memoirs of a few broadcasters and interviews they have given to various Arabic newspapers as well as on contributions successive broadcasters have made to the monthly magazine, Huna London, the Service's own equivalent of Radio Times. Douglas A. Boyd's series of surveys concerning international radio broadcasting to Arabic-speaking countries, ${ }^{8}$ as well as Peter Partner's well-informed Arab Voices, ${ }^{9}$ make up a range of fairly relevant and enlightening secondary sources for this study. I also rely on reports, press accounts and radio programme schedules tracked down throughout a large digitalised private collection of Huna London. 
5 The long lifetime of the BBC Arabic Service will be scrutinised through four main distinct periods: 1938-1945, 1945-1956, the 1960s-70s and finally the 1980s-90s. The perspectives of the Service into the current century will be alluded to in the conclusion.

\section{PBS, a Precursor To BBC Arabic?}

6 Before creating its own Arabic service, the BBC, in collaboration with Guglielmo Marconi, a physicist and entrepreneur in the wireless technology and co-founder in 1922 of the British Broadcasting Company that led to the creation in 1927 of the present-day public service body, had by the mid-thirties been substantially involved in setting up national radio stations in Egypt and Palestine. The latter is a case in point. The Palestine Broadcasting Service (PBS) operated from March 1936 to May 1948 and broadcast in Arabic, Hebrew and English. Its cultural broadcasts played an important role in the development of interwar Palestinian and Zionist national identities reflecting the station's concept of the dual commitment the British had to both the Arab and Jewish populations of Palestine. In a long-awaited comprehensive history of PBS, the American scholar Andrea Stanton ${ }^{10}$ provides a full account of this governmentsponsored radio that catered to various audiences thus shaping middle class culture in the mandate territory almost on the model of the future BBCWS. The account shows that the impact of the $\mathrm{BBC}$ behind the project cannot be mistaken and that its involvement in it was going to be instrumental for the programming of the future $\mathrm{BBC}$ Arabic. Andrea Stanton investigated the Arabic section programming as an illustration of the station's capacity to serve as a vehicle for a Palestinian national modernity through a vibrant middle class but she also describes programming designed for the education of the peasantry in better farming techniques and better hygiene on the model of a similar action the BBC had sponsored in colonial India. Regarding the introduction of religious content in the programmes for instance, Ms. Stanton's book points out that the station catered to the three faiths of the local population. She argues that

putting religion on the radio in Palestine helped transfer to the region a British concept of radio as a public good overseen by the government (...) The British mandate government had modelled the PBS on the BBC, translating the latter's commitment to spreading morality through Christian broadcasts into a promise to respect the "claims of religion" for Palestine's faiths. ${ }^{11}$

7 A comparable position can be observed in the future BBC Arabic. Indeed, the Service made the conscious decision to begin a day's programme with a reading from the Qur'an, a practice that continued for fifty years. Peter Partner, a historian and former contributor to the Service and to whom, in 1988, the Corporation entrusted the task of writing a fiftieth anniversary presentation of $\mathrm{BBC}$ Arabic, asserts that

the Quranic broadcasts certainly did not seem strange to the Englishmen in the Service, with their conviction that the Service should play a part in the renaissance of Arab culture and in the affirmation of its traditional values (.) The religious readings of the Arabic Service were never perfunctory. In Egypt religious broadcasting was one of the main links between the urban culture of the broadcasters and the rural masses. ${ }^{12}$

It might be worth exploring whether $\mathrm{BBC}$ Arabic was throughout the period under study an instrument of Britain's soft power in the Middle East or it was free from political interference. Likewise, were the Arab broadcasters themselves instruments of 
"the projection of Britain" in the region or did they ever indirectly challenge the radio's stance? Indeed, as part of the wider BBC, the Arabic Service was designed to fulfil a public service mission while maintaining its role as a "soft power" agent for the UK, though necessarily a nuanced one, due to the difficult paradox of embracing the concept of "the projection of Britain" and at the same time abiding by the Corporation's commitment to independence from government.

\section{The Projection of Britain}

But what exactly was to be projected through a foreign language wireless station in the first place? The concept was at the heart of burning issues of international concern in the mid and late 1930s of the last century. As early as 1934, Germany and Italy began to exploit the emerging radio short-wave technology for propaganda purposes towards Middle Eastern audiences thus challenging the British government to follow suit and to consider instituting foreign language broadcasts to counteract their influence. The two far-right regimes had shown a keen interest in exploiting the outbreak of the Arab Revolt (1936-1939) against British colonialism in such a way as to make British presence in the region more vulnerable. Considering British disdain for crude propaganda, the theorisation of a kind of "British projection" which aimed at selling a commercial and cultural image of Britain rather than a political one became prominent and drew increased government interest in it. Two men were actively involved in the making of the new doctrine. Sir Stephen Tallents, a civil servant involved in the burgeoning public relations industry, is the one who coined the phrase in 1932 in his book, The projection of England,,$^{13}$ and Reginald Leeper, head of the Foreign Office News Department and a major founding figure of the British Council set up in 1935-an institution which, to use Peter Partner's terms, "corresponds in many ways to the kind of instrument of national projection proposed by Sir Stephen Tallents". ${ }^{14}$

10 For British foreign policymakers the very idea of implementing a projection of Britain abroad by means of foreign language broadcasting was a timely and welcome perspective. Both Tallents and Leeper were influential members of the committee that was set up for that aim at the beginning of 1937. The Conservative Minister of Health, Kingsley Wood, who had been responsible for the BBC in earlier governments as Postmaster General, headed the committee. At first, the BBC was not invited to join in the discussions as the Foreign office was hoping for a rather more malleable and less independent voice than the chartered public body. Moreover, from within the BBC itself, officials from the Empire and Colonial Service (a venue of short-wave broadcasts in English destined to the colonies since 1932) disapproved of introducing foreign languages altogether, arguing that the simple fact of broadcasting in a foreign language could be perceived as indulging in propaganda. Actually, the original Empire service had not been intended as a projection of British power, but as an extension of the BBC's service to white people living under the British flag in the Dominions and the colonies. Given the emergency and the extent of the obstacles met by a projected station in Cyprus, the Foreign office ended up extending the negotiations to the BBC with a view to making it launch an Arabic Service to be conceived as an exercise in what they called "the art of national projection" but what Sir John Reith, Director-General of the BBC, called " the projection of British culture in other languages." ${ }^{15}$ Within the Committee the objection to the launching of an Arabic Service came from Reginald Leeper who did not 
hide his Latin American sympathies and insisted on prioritising Spanish and Portuguese. Eventually the three languages discussed constituted the first wave of overseas services to go on air starting from January 1938 with Spanish and Portuguese services to be launched a few weeks after the Arabic one. Persian and Turkish services as well as German, Russian, French and around ten other European languages followed between 1939 and 1942.

On 21 July 1937 the Cabinet Committee on Overseas Broadcasting in charge of assessing the Kingsley Wood Report agreed to abide by the BBC's claim for factual presentation of the news and editorial independence in harmony with the terms of the existing Licence and Charter. As Peter Partner asserts, "Lord Reith was not going to offer the Foreign Office a Trojan horse in which to enter the BBC. In other words, he was not going to do a deal over the foreign language broadcasts which did not include proper guarantees of editorial independence." 16

The same Cabinet committee settled the matter of financing the projected service, too. There was an agreement that in addition to funding through the wireless and later the TV set licence fee due to the Corporation's status as a public service, the projection dimension dedicated to the new-born service required the creation of an extra resource granted jointly by the Empire office and the Foreign Office. It was the aptly named grants-in-aid for which the Diplomatic Wing of the Foreign office was to be accountable to Parliament.

\section{8-1945: The Era of the "Golden-Voiced" Sourour and Sabbagh}

13 On 4th January 1938, after an announcement in English by Director-General John Reith in which he declared that the foreign language service would always be "reliable, accurate and interesting," values that have become virtually cast in stone as the Reithian model of broadcasting, the so-called "golden-voiced" presenter Ahmad Kamal Sourour Effendi, who had been recruited from the Egyptian radio service, introduced the Corporation's first foreign language broadcast in Arabic which consisted of a news bulletin. The following day the fifteen-minute-long event was debated in the House of Commons where it received a warm welcome from MPs and Cabinet members. That first news bulletin nonetheless proved to be perhaps the most controversial in the history of the Service. It clearly showed the Corporation's colours in providing from the very start a witness of a testimony of factual and impartial news. The disputed piece of news went on as follows: "Another Arab from Palestine was executed by hanging at Acre this morning by order of a military court. He was arrested during recent riots in the Hebron Mountains and was found to possess a rifle and some ammunition."

Sir Reader Bullard, British ambassador to Saudi Arabia who attended the reception organised by the Saudi king so that his Court and guests might listen to the inaugural broadcast, reports in his autobiography that the Arab ruler wept in grief when Sourour spoke of the execution and said: "if it had not been for the Zionist policy of the British government that Arab would be alive now". Further in the autobiography Sir Bullard asserts: "I have always been in favour of trying the effect of broadcasting accurate and interesting news from England, but never prepared to believe that the effect in the Near East will be very great, so long as the Palestine question existed to poison the atmosphere." ${ }_{17}$ 
Peter Partner quotes a similar declaration by the Ambassador to Cairo saying: "As long as our policy in Palestine remains unacceptable to the Arab world, the Italians must continue to have a very great advantage over us in propaganda, Palestine will remain a thorn in the flesh until our line is changed: it is in fact a veritable mill stone round our neck." ${ }^{18}$ Obviously, both diplomats show an acute awareness of the fact that the Palestine question ruined British efforts at exerting a form of soft power through radio.

As for the Corporation, it justified its new-born Service's blatant announcement by pointing out that the piece of news had already appeared on the Empire Service bulletin and expressed its satisfaction through George Rendel, the head of the Eastern Department, saying "the fact that we had not concealed this item of news was a guarantee of our statement that our news would be straight news, and not carefully selected for the audience." ${ }^{19}$ Unsurprisingly, the news item announcement appalled Foreign office circles who accused the BBC of breaching of the spirit of the Kingsley Wood Committee Report.

Ahmad Kamal Sourour Effendi (1910-1972) started his career as one of the founding fathers of the Egyptian national radio set up with the help of the BBC and Guglielmo Marconi in 1934. Nicknamed "the golden voice," Sourour shared his wide popularity with his fellow citizen Hussein Elkarmi and the Palestinian Isa Sabbagh, both of whom he had worked with in Cairo. In 1943 Ahmad Sourour was sent to France as war reporter. Elkarmi got to be known as the presenter of the political programme Kawlon Ala Kawl (Saying on Saying) for the following thirty years. As for Isa Khalil Sabbagh (1917-2000), he also enthralled his Arab listeners with his voice as an influential war reporter. He soon emigrated to the United States where he was asked by the State Department to start up the Arabic Service of the Voice of America, which he directed for more than seven years before taking up a long career as a US foreign service officer and a special envoy to Saudi Arabia. He made full use of his fame to establish personal relations with King Faisal who had heard him on the BBC.

18 Until the end of the war the whole transmission time began with 65 minutes a day to end up with 3 hours. The dominant atmosphere in this inaugural era was its classicist touch. Albert Habib Hourani, founder of Middle Eastern Studies centre and journal at Magdalen College, Oxford, describes the programming when dwelling on his father's tenure in the Service as a happy coincidence between an age of literary revival in the Arab world and a deep affection for the values of late-Victorian England. Indeed, Faldo Hurani gave talks in the 1940s in a memorable series on BBC Arabic called "Fifty Years in England" in which he praised the idyllic beauty of the country where he had landed as a Lebanese immigrant in the late nineteenth century.

Undoubtedly, the most distinguished literary contributor at the time was the Egyptian writer Taha Hussein (1889-1973) who gave in 1955 a series of unscripted talks on preand post-Islamic literature. He had already begun the series with a first script in May 1938 an essay on the Christian Umayyad poet, al-Akhtal. The two other Egyptian writers who were particularly appreciated by listeners were Tawfik all-Hakim and Abbas Mahmud al-Akkad. Those high-profile literary figures enhanced the popularity of the programmes that were presented by even more popular announcers.

The type of Arabic to be used by the Service's announcers and broadcasters was much discussed beforehand. The standard of the $\mathrm{BBC}$ had to be different from other international radios. It was established that Radio Bari hired Tunisian announcers whose dialect could not generally be understood by potential listeners in large parts of 
the Middle East. That is why the type of Arabic that should be used in its broadcasts was a point of concern the Corporation had to consider carefully. There was a keen awareness that in order for the proposed broadcasts to be both widely understood and taken seriously, making the appropriate linguistic choice was crucial. As a matter of fact, one of the achievements, and not the least, of Sourour, Sabbagh, Gom'aa and the rest of that first wave of native recruits was the major part played by the Service in the development of a media Arabic throughout the twentieth century, that is to say, the emergence of educated spoken Arabic as distinct from both classical Arabic and the various regional and national dialects that exist throughout the Arab world. Indeed, what fascinated generations of listeners was the melodic and enchanting enunciation of the announcers uttering hour after hour the famous "Huna London" (this is London) that followed the fascinating chimes of Big Ben.

\section{8-1956: Muneer Shemma, the Rebel Diplomat}

21 The tenth anniversary of the Service coincided with the end of the British Mandate in Palestine and the evacuation of the Sharq al Adna station from Jaffa to Cyprus, which forced Palestinian members of its staff to migrate. BBC Arabic recruited a number of them. The most famous of those recruits was Muneer Shemma (1919-2013). No doubt, his celebrity preceded him in Broadcasting House following the performances he had had as a wartime propagandist for the Jaffa-based British station. Especially the epic remote duels he had had with Yunes Bahri, the Berlin radio propaganda star. Though it could not be denied that the British authorities exercised some kind of control over Sharq al Adna, no government publicly recognised its connection with the Foreign Office or any of the British intelligence services. As for the BBC, it was quite wary of becoming too involved with Sharq al Adna for fear that it may tarnish its reputation of impartiality. However, the light programming of the station made it very popular in the Middle East and its star announcer and political commentator Muneer Shemma was especially remembered for his roaring wartime reports.

In Broadcasting House, where the Arabic Service was still located, Muneer Shemma started as a news announcer and political commentator, but he soon built himself a reputation as an outspoken debater thanks to his stint in Sharq al Adna radio, though this was going to be a little treacherous to him in a constitutionally inhibited place such as the BBC. On the other hand, those traits enabled him to turn into a shrewd diplomat and Foreign Office officials often hired him as a translator and protocol facilitator on visits of Arab ministers and even heads of State. His reputation as an orator and political agitator is well reflected in his Diary of an Ageing Palestinian published in Jordan in $2010^{20}$ in which he shares his recollections about his stint at the BBC. The memoirs are teeming with political revelations and accounts that deserve to be made known, especially in the case of a heated debate on the Palestinian issue he had in 1946 at a reception in the Saudi embassy in London with the prominent Labour Left-wing figure Aneurin Bevan.

Neville Barbour, Assistant Head of the Eastern Services of the BBC, asserts ${ }^{21}$ that the predominance of news in the period (four daily bulletins in a total of three hours of programme material) reflected the extent of the British interest in the Arab world. Furthermore, the news bulletins were supplemented with increasingly popular political shows. The most successful was Brains Trusts, in Arabic, Assiyassa Bein essaili wal mujeeb, 
an informational BBC radio and later TV programme that was popular in the 1940s and 50 s in which a panel of experts were invited to answer questions sent in by the audience. Usually the guests were prominent Arab politicians. Muneer Shemma was instrumental in inviting the Tunisian nationalist leader Habib Bourguiba on Brains Trusts on 26 July 1951 in which Bourguiba expressed his gratefulness to the BBC for giving him the opportunity to speak on the radio for the first time.

As the policy of Sharq al Adna, where he had completed the bulk of his broadcasting career, was deliberately intended to favour the Arab cause, Muneer Shemma started his stint on BBC Arabic quite emboldened by a nationalist and polemic spirit. Mistranslations and twists of diction often cost him severe warnings from his hierarchy. He would repeat such tactics especially over the outbreak of the Suez crisis in October 1956 and this was the final straw that led to the termination of his contract which may explain why Peter Partner retrospectively underplayed him in his 1988 official opus where indeed there is no mention of his name at all. Employment contracts at the World Service were rarely long-term ones in any case. In the wake of Tunisia's independence in 1956, Bourguiba, now Prime Minister, aware of Shemma's dismissal (he insisted in his memoirs that it was a resignation) from the $\mathrm{BBC}$, provided him with a welcome home in Tunis and a mission to help set up the country's national radio.

While such excesses were part of the trend of the times, it would be misleading to suggest that they were of great importance inside the Arabic Service, which remained in line with the Corporation's stance over the Suez crisis. With the benefit of hindsight, Suez is widely recognised as the most serious crisis ever covered by the public-owned news organisation. The Arabic Service's reporting helped shape the Corporation's stance on this historic event. In a nutshell, the stance consisted in a cautious condemnation of any attempt to humiliate President Nasser, warning that such a trend would turn the tide of sympathy for Egypt. The Service however did tolerate a few jokes mocking the Egyptian leader on its programme. Incidentally, the Suez crisis coincided with a resurgence in the Arab world of a revolutionary ferment that did not fail to have an impact on native broadcasters such as Muneer Shemma who was perhaps one of the rare presenters who challenged British policy over Suez. He showed that attempts at exerting soft power could be challenged from within BBC Arabic. It should be noted that the same discomfort made itself felt in the listeners' letters, too. The question remained, however, whether providing a platform for increasingly vocal dissenters would sour relations between the Corporation and the government, but at the end of the day what mattered was that like with its counterparts in the wider BBC, journalism in the Arabic Service remained relatively independent.

\section{The 1960s and 1970s: Tayeb Salih and the Shift to the Light Programme}

Though the daily transmission time grew only slowly, undoubtedly the 1960 s and 1970 s era will be remembered as the heyday of $\mathrm{BBC}$ Arabic. Its photo albums stored in the BBC Photograph Collection Archive abound with shots of Heads of State, famous writers and popular singers and artists from around the Arab world taken during highlighted visits to Bush House. The well-known Lebanese singer Fairuz visited the BBC in 1961 with her famous composers the Rahabani brothers; her fellow citizen Sabah and 
Egyptian musician and composer Mohamed Abdelwahab followed in 1962. All these artists were invited to Bush House as confirmed icons in the Arab world most likely to enthral the Service's listeners. A shift to a trendier mode of programming was obviously taking shape. This especially meant moving away from a predominantly news and talks on current affairs broadcasting to a more varied programme of music, plays and features.

Also, a wind of modernism was blowing over Huna London and new blood was infused in its editorial content as high-profile journalists living in London at the time, such as Mustafa al-Karkuni, founder of the Lebanese daily newspaper Essafir (The Ambassador), contributed for many years to the Service's monthly magazine.

On the other hand, English language learning, a staple in the programmes as well as through the pages of Huna London since the late forties, experienced the same trend of change, too, following the progress made in the field's theoretical and methodological framework back then.

The shift is also characterised by a trend of feminisation in members of staff recruited. Palestinian Madiha Elmadfa read the news in the sixties while Egyptian news presenters Hoda Errachid and Salwa Jarrah followed in the 1970s. Yet the recruitment in this period was dominated by a male writer, the Sudanese Tayeb Salih (1929-2009) who is still recognised as one of the greatest Arab novelists alongside Nobel winner Naguib Mahfuz. For Tayeb Salih, the exiles or diasporas phenomenon was both a personal story he experienced in London and a vivid representation in his work of fiction, mainly his famous novel Season of Migration to the North (1966) for which he won fame. When he graduated from the University of London he was recruited by the BBC to serve first as a broadcaster and then as a director of the BBC's Arabic drama department. He wrote his well-known novel while he was serving at the BBC. In this complex and poetic story he dealt with the co-existence of civilisations mitigated by a mixture of illusion and mutual enrichment between Eastern and Western cultures.

On the whole, the change of tone in the World Service cannot be separated from the 1967 turning point that marked programming in the wider BBC, when the whole structure of $B B C$ radio production was transformed. Some parallels can be noticed between $\mathrm{BBC}$ Arabic and the domestic services. Far from segmenting its audience into classical (as with The Third programme that turned into Radio 3 in 1967) and the Light Programme (Radio 2 since 1967), of course, the Tayeb Salih era can be seen as a turning point in BBC Arabic programming, too. Gone was the elitist spirit of the earlier periods reflected for instance in Taha Hussein's lectures on pre-Islamic Arab poetry to give way to a rather mainstream and light kind of broadcast, which did not mean, of course, that classical Arab music, literature and discussion were now forsaken. The proof of that is that the great novelist Tayeb Salih was head of the drama department with a mission to infuse in the programming both his taste for popular culture and postmodernism that prevailed throughout the era.

\section{The 1980s and 1990s: The BBC and the Making of $A l$ Jazeera}

31 This last period is characterized by a turning point in the international media landscape marked mainly by the advent of round-the-clock radio and TV news outlets. 
According to the 1991 National Audit Report, the Service was still, by far, leading the Overseas section of the BBC with its 78 full-time staff consisting of six managers, 46 management support staff, with a further five involved with publications. The Service's average of seventy hours output a week contrasted with the BBC Russian's fifty-six hours or more strikingly, with the BBC French's twelve hours per week. The same report points out an interesting fact that can explain such disproportion: "The number of languages and broadcast hours which are funded by the grants-in-aid are defined in the Prescription which is determined by the Foreign and Commonwealth Office in consultation with the World Service," the Report recalls, arguing that the Prescription can be adjusted to respond to a number of international crises and developments and according to a grading of low, medium and high foreign policy priority areas. As a matter of fact, the Arabic's quota during the Gulf War rocketed from sixty-three to a peak of ninety-eight hours broadcast per week making it the largest vernacular service by far.

The mid-nineties were also a season for many of the Arab broadcasters at Bush House to migrate south. They moved in the opposite direction compared to broadcasters in the previous periods. Indeed, in 1996 a whole crew of seventeen experienced BBC Arabic broadcasters moved to brand new Doha studios in Qatar to become the skilful architects of al Jazeera, a round-the-clock TV outlet sponsored by the wealthy Gulf monarchy. The rise of al Jazeera as a BBC-inspired station has left an indelible mark on Middle East politics, invigorating the region's dull media landscape. Although run by professionals steeped in the BBC standards, al Jazeera did not manage to live up to the expectations of $\mathrm{BBC}$ ethics as things were rapidly evolved in the Middle East leading the Qatari news outlet to soon change its stance and come under close scrutiny by its wagepayers to ensure a pro-Muslim Brotherhood discourse.

What is more striking is that al Jazeera was, to a certain extent, the offspring of a pitiful BBC misadventure. The story dates back to 1994 when the Corporation signed a deal with the Saudi-owned company Orbit Communications to provide Arabic TV newscasts for Orbit's main Middle East channel. However, the BBC's insistence on editorial independence clashed with the Saudi's unwillingness to allow reporting on controversial issues. The station went off- air in April 1996 when the Saudi Government objected to the BBC programming a news item about King Fahd being admitted to hospital. Due to a lack of alternative funding then, former BBC recruits, the Arabicspeaking television journalists trained by the Corporation went off to set up al Jazeera. In 2005 when the Corporation dropped seven of its forty languages services to finance a sounder project for an Arabic-speaking TV channel, once more a pioneer in nonEnglish language, The Economist ${ }^{22}$ criticized the Corporation for the belated sacrifice, arguing that it could have been made in the wake of the 1994-1996 failed stunt.

Perhaps the brightest and most high-profile of the seventeen broadcasters who made the crossover from the BBC to al Jazeera in 1996, was the British-Syrian veteran and television personality Faisal Al-Qassam. He entered al Jazeera after he had worked for the BBC Arabic Radio and TV for over eight years as a news producer and anchor of political and cultural programmes. Al Ittijah al Muakiss (The Opposite Direction) the controversial live debate show with which he made his fame on al Jazeera, where two guests with contradictory points of view debated on a burning issue related to Arab world politics, recalled the show Min Wara al Akhar (Behind the News) which he had presented on the short-lived BBC Arabic Television experience of 1994-1996. 


\section{Conclusion}

As the $\mathrm{BBC}$ approaches its centenary, it seems appropriate to consider whether the search for objectivity is still present in the output of its oldest foreign language service. In an era of cable satellite and interactive media, the BBC's status as a publicly funded body (a non-Departmental Public Body, in Whitehall terms) is increasingly questioned and it has frequently been accused of an "institutional liberal bias," a phrase put forward by the Corporation's veteran broadcaster, John Humphrys, who, days after retiring, described the liberal Left as "the spiritual home of most BBC's bosses and staff." ${ }^{23}$ At a time when Middle Eastern issues continued to be the most sensitive news organisations had to deal with, the $\mathrm{BBC}$ chose by the mid noughties, following persistent allegations from the Israeli government of anti-Israeli bias, to create a senior editorial post to advise its Middle East coverage. As a matter of fact, Malcolm Balen, a senior news editor in the Corporation, was commissioned in 2004 to investigate the case and his twentythousand-word report was meant as an internal review to help shape future policy on the BBC's Middle East coverage and was never intended for publication. However, the matter hit the headlines when Steven Sugar, a lawyer, challenged the Corporation first before the Information tribunal and then before the High Court to disclose the report. Incidentally, the Freedom of Information Act insisted on the BBC's position as a public authority and thereby allowed it under an exclusion clause to refuse requests when information is deemed to be held "for purposes of journalism, art or literature."

Though the Arabic Service was not specifically targeted by the allegations, nor were the Report's recommendations tailored for its exclusive practice, inconsistent use of language in some of its broadcasts was explicitly pointed out by Malcolm Balen. Such a flaw, however, has often been in the spotlight over the decades, though, considering Middle Eastern political twists and turns, they have often been blamed on translation nuances. At the same time, the $\mathrm{BBC}$ reporting of the Israeli-Palestinian conflict was often reproached with implicitly favouring the Israeli side when the deaths of Israelis received greater coverage than the Palestinian fatalities. In 2006 a study of the BBC governors-now the BBC Trust-reacted to both complaints asserting that there was " little to suggest deliberate or systematic bias" in the coverage of the conflict, "On the contrary, there was evidence of a commitment to be fair, accurate and impartial." ${ }^{24}$

Pressure from both pro-Israeli and pro-Palestinian groups is obviously a tremendous strain on the BBC's ability to provide balanced broadcasting and to maintain its political independence.

In the wake of the turmoil around the Balen Report a spokesperson of the Corporation told The Guardian:

Free and impartial journalism is vital to our viewers and listeners and is at the heart of public service broadcasting. If we are not able to pursue our journalism freely and have honest debate and analysis over how we are covering important issues, then how effectively we can serve the public will be diminished. This was recognised by parliament in creating the 'journalism' designation for the public service broadcasters in the first place. ${ }^{25}$

Come what may, the success of $\mathrm{BBC}$ Arabic has never diminished and, well in its ninth decade, the Service is still the largest in terms of programming time and number of staff. In spite of slicing off the schedules of a whole range of radio shows and the move out of Bush House, a mini United Nations now scattered in the vastness of the 
Corporation's new headquarters, the Service still enjoys vigorous health. Broadcasting in the Arabic language was extended to television as the Corporation's initiative to branch out into non-English television finally came into existence in 2008 and the following year the new station shifted to round-the-clock broadcasting. As far as online services are concerned, BBC Arabic website is by far the most visited in this language. Obviously, beyond such a stunning success lies the rank of the BBC as the best example of cultural exchange through its World Service which takes on an active role in the projection of Britain while appealing to large and various foreign audiences who respond in tribute and recognition of its concern for their own societies and cultures. In so far as the present case study is concerned, the mediation of this concern has to a large extent been accomplished by the diasporic Arabic speakers of the Service who, while carrying out the broadcasting from Bush House, played a key and valuable role in the service's appeal.

Until the advent of electronic mail and the decline of snail-mail, the BBCWS had always measured the quality of its listenership by monitoring the number of letters received from the target audiences. According to the 1991 Report of the National Audit Office, over 17, 260 listeners' letters were received by the Arabic Service in the first seven months of that year. Statistics show the number of letters per year increased from 8 , 000 in 1955 to an average of 21, 000 in the five years following Suez to exceed 26, 000 letters in 1975. In 1985, letters from listeners were being received at the rate of 80000 a year, a twofold increase since the 1960s. For those thousands of listeners who, generation after generation, put pen to paper in bursts of praise or complaint, the $\mathrm{BBC}$ is, in some significant way, their Beeb, too. Their Auntie who knows best.

\section{BIBLIOGRAPHY}

Barbour, Neville « Broadcasting to the Arab World: Arabic Transmissions from the BBC and Other Non-Arab Stations » in Middle East Journal, Vol.5, N 1 (Winter 1951), pp. 57-69.

Baumann, Gerb and El Issawi, Fatima, "The BBC Arabic Service: Changing Political Mediascapes" in The Middle East Journal of Culture and Communication, Vol.3, Issue 2 (Jan 2010), pp. 137-151.

Boyd, Douglas A., "International Broadcasting in Arabic to the Middle East and North Africa" in International Communication Gazette, Leiden (August, 1976), pp.183-196.

Briggs, Asa, The History of Broadcasting in the United Kingdom, Vol.I (Oxford, Oxford University Press, 1965).

Bullard, Reader, The Camels Must Go: An Autobiography (London, Faber and Faber, 1961).

Gillespie, Marie, Alban Webb (eds.), Diasporas and Diplomacy: Cosmopolitan Contact Zone at the BBC World Service, 1932-2012 (Abingdon, Routledge, 2012).

Gillespie, Marie "BBC Arabic, social media and citizen production: An experiment in digital democracy before the Arab Spring" in Theory, Culture and Society, vol. 29 (2013), pp. 92-131.

Partner, Peter, Arab Voices: The BBC Arabic Service,1938-1988 (London, BBC External Services, 1988). 
Shemma, Muneer, Diary of an Ageing Palestinian (Amman, Toubkal, 2010) (in Arabic).

Stanton, Andrea, This is Jerusalem Calling: State Radio in Mandate Palestine (Austin: University of Texas Press 2013).

Tallets, Stephen, The Projection of England (London, Faber and Faber, 1932 ), (London, Ollen Press, 1955).

$* * *$

BBC, "The Use of Languages Other than English in the Empire Service" R34/399 (Reading, Caversham Park, BBC Archives Centre, 1962).

"BBC Report Middle-East", The Guardian, 2 October 2002. Available on <https:// www.theguardian.com/media/2009/oct/02/bbc-report-middle-east>. (consulted in June 2020).

"Bush House of Arabia", The Economist, 27 October 2005.

Huna London (London, British Broadcasting Corporation, selected issues, 1961-1985) (Private collection, Arabic).

“John Humphry Hits Out at BBC for Institutional Libel", The Independent, 26 January 2008. Available on https://www.christian.org.uk/news/john-humphrys-hits-out-at-bbc-forinstitutional-liberal-bias/. (consulted in June 2020).

Report by the controller and Auditor General: Management of the BBC World Service (London, House of Commons, 15 May 1992). Available on https://www.nao.org.uk/pubsarchive/wpcontent/ uploads/sites/14/2018/11/Management-of-the-BBC-World-Service.pdf, (consulted in June 2020).

\section{NOTES}

1. Baumann, Gerb and El Issawi, Fatima, "The BBC Arabic Service: Changing Political Mediascapes" in The Middle East Journal of Culture and Communication, Vol.3, Issue 2 (Jan. 2010), pp. 137-151. Gillespie, M., "BBC Arabic, social media and citizen production: An experiment in digital democracy before the Arab Spring" in Theory, Culture and Society, Vol. 29, (2013), pp.92-131.

2. John Reith (1889-1971) was BBC's first director general (1927-1938). His legacy is so overwhelming that the term "Reithian values" has become a byword for independent public service broadcasting.

3. https://artuk.org/discover/artworks/the-sower-251286 (consulted in June 2020).

4. The English language World Service and an average of 37 other services in foreign languages during the studied period are all part of the BBC's External Services known in 1932 as Empire and Colonial Services. In 1939 German was introduced and later on, in 1942, broadcasting was extended to major European languages so the Service was renamed BBC Overseas Service, until 1965 when the current name BBC World Service (BBCWS) was adopted. Administratively, the External Services are divided into European and Eastern Services. The BBCWS is an integral part of the $\mathrm{BBC}$ and is covered by the same Licence and Charter as the BBC's domestic services. It had been funded for decades by grants-in-aid through the Foreign and Commonwealth office until 2014 when its funds came to be limited to UK television licence fee. However, the Service has since been allocated around three million pounds over a five-year period from the Foreign office budget. The British government is responsible for deciding the language in which programmes are broadcast as well as the length of time each language is on the air, but their content is the responsibility of the $\mathrm{BBC}$. The number of languages has been reduced to 27 in recent years due to increasing cuts in government grants. 
5. Bush House in central London is the iconic building that was home to the BBC World Service between 1941 and 2012. At its launch, BBC Arabic was located in Broadcasting House, the Corporation's emblematic headquarters which was inaugurated in 1932. During the Blitz (September 1940-May 1941), the Overseas Services were relocated to Oxford Street while the European Service was the first to enter Bush House in 1941 and the rest of the Overseas Services followed in 1958. Subsequently, the building gained a global reputation as the home of the BBC World Service. However, in 2012, with the end of its lease and the completion of the New Broadcasting House in Shepherds Bush, West London, where the various services of the BBC are currently located, Bush House was vacated before becoming the property of neighbouring King's College.

6. Marie Gillespie, Alban Webb (eds.), Diasporas and Diplomacy: Cosmopolitan Contact Zones at the BBC World Service, 1932-2012 (Abingdon, Routledge, 2012).

7. Due to the closure of onsite facilities of the BBC Written Archives Centre at Caversham Park with regards to the outbreak of Coronavirus, the Centre could only provide via e-mail search for answers to short queries such as the provision of details about a BBC staff member, programme or contributor.

8. Douglas A. Boyd, "International Broadcasting in Arabic to the Middle East and North Africa" in International Communication Gazette, Leiden, (August, 1976), pp.183-196.

9. Peter Partner, Arab Voices: The BBC Arabic Service,1938-1988 (London, BBC External Services, 1988).

10. Andrea L. Stanton, “This is Jerusalem Calling”: State Radio in Mandate Palestine (Austin, University of Texas Press, 2013).

11. Ibid., pp.167-168.

12. Partner, op. cit., p. 62.

13. Stephen Tallents, The Projection of England (London, Faber and Faber, 1932), (London, Olen, 1955).

14. Partner, op. cit., p. 3

15. Ibid., p. 4.

16. Ibid., p. 6.

17. Reader Bullard, The Camels Must Go: An Autobiography (London, Faber and Faber, 1961). Quoted in Patner, op. cit., p. 18.

18. BBC, "The Use of Languages Other than English in the Empire Service" R34/399 (Reading, Caversham Park, BBC Archives Centre, 1962). Quoted in Partner, op. cit., p.18. see also Asa Briggs, The History of Broadcasting in the United Kingdom, Vol.1 (Oxford, Oxford University Press, 1965).

19. Partner, op.cit., p.19.

20. Muneer Shemma, Diary of an Ageing Palestinian (Amman, Toubkal, 2010) (in Arabic).

21. Neville Barbour, "Broadcasting to the Arab World: Arabic Trasmissions from the BBC and Other Non-Arab Stations" in Middle East Journal, Vol.5, №1 (Winter 1951), pp. 57-69.

22. The Economist, 27 October 2005. https://www.economist.com/britain/2005/10/27/bushhouse-of-arabia (consulted in June 2020).

23. The Guardian., 21 September, 2019. https://www.christian.org.uk/news/john-humphrys-hitsout-at-bbc-for-institutional-liberal-bias/ (consulted in June 2020).

24. Quoted in The Independent, 26 January 2008.

25. The Guardian, 9 October 2009. https://www.theguardian.com/media/2009/oct/02/bbc-reportmiddle-east (consulted in June 2020) 


\section{ABSTRACTS}

This article sheds light on the origins and long-term progress of the Arabic Service of the BBC. It is therefore closely concerned with the BBC's coverage of the particularly sensitive politics of the Middle East since the 1930s and thereby the delicate relationship between the BBC and the British government. The article also shows how the BBC managed to make its Arabic Service an integral part of modern Arab culture and how with the help of skilful broadcasters recruited among the Arab diaspora the Service's programming testifies to a remarkable history of cultural interchange.

Cet article retrace les origines et l'évolution du service arabe de la BBC et par ce billet il traverse l'histoire politique et culturelle contemporaine du monde arabe telle qu'elle a été couverte par la $\mathrm{BBC}$ depuis les années trente. Compte tenu des rapports spéciaux du Royaume-Uni avec le Moyen Orient, l'article lève le voile sur certains aspects des relations délicates entre la BBC et le gouvernement britannique. L'article montre également comment la $\mathrm{BBC}$ a réussi à faire de ce service pionnier en langue étrangère une partie intégrante de la culture arabe moderne et comment de fructueux échanges culturels se sont tissés à travers de talentueux journalistes de radio recrutés dans la diaspora arabe.

\section{INDEX}

Mots-clés: Service Arabe de la BBC, radiodiffusion, diaspora, Moyen Orient, media, soft power

Keywords: BBC Arabic, broadcasting, diaspora, Middle East, news media, soft power

\section{AUTHOR}

\section{HOUCINE MSADDEK}

INSA, Strasbourg

Houcine Msaddek teaches English at Institut National des Sciences Appliquées (INSA), Strasbourg. He wrote his PhD thesis about the British trade unions' press and the European integration and has published several articles about the trade union movement, media and discourse analysis.

Houcine Msaddek enseigne à l'INSA de Strasbourg. Ses travaux de recherche portent sur la société britannique contemporaine, en particulier le mouvement syndical, les médias et l'analyse de discours. Il est l'auteur d'une thèse sur la presse syndicale britannique et l'intégration européenne. 